\title{
Lamellar ichthyosis
}

INSERM

\section{Source}

INSERM. (1999). Orphanet: an online rare disease and orphan drug data base. Lamellar ichthyosis. ORPHA:313

Lamellar ichthyosis (LI) is a keratinization disorder characterized by the presence of large scales all over the body without significant erythroderma. 